\title{
FACTORS AFFECTING BACTERIA CONTAMINATION AMONG FOOD HANDLERS AT A PUBLIC HOSPITAL IN SOUTH SUMATRA, INDONESIA
}

\author{
UTARI, S. ${ }^{1,2^{*}}-$ HERMANSYAH $^{3}-$ SALEH, I. ${ }^{4}-$ PAMBAYUN, ${ }^{5}$ \\ ${ }^{1}$ Environmental Science Department, Sriwijaya University, Palembang, Indonesia \\ ${ }^{2}$ The South Sumatera Provincial Health Office, Health Training Center, Palembang, Indonesia \\ ${ }^{3}$ Department of Chemistry, Faculty of Mathematics and Natural Science, Sriwijaya University, \\ Palembang, Indonesia \\ ${ }^{4}$ Department of Medical, Faculty of Medical Science, Sriwijaya University, Palembang, \\ Indonesia \\ ${ }^{5}$ Department of Agricultural Technology, Faculty of Agriculture, Sriwijaya University, \\ Palembang, Indonesia \\ *Corresponding author \\ e-mail: utariutari76@yahoo.com; phone: +62-813-677-70208
}

(Received $11^{\text {th }}$ Feb 2019; accepted 28 $8^{\text {th }}$ Mar 2019)

\begin{abstract}
Food-borne diseases caused by pathogenic bacteria (especially Escherichia coli) are one of the main causes of mortality in some developing countries. Hospitals are one of the potential places from where food-borne diseases might spread. The food handlers working in the hospital have a major role in the distribution of pathogenic bacteria because they are directly involved in the hospital's food chain. This study aimed to determine bacteria contamination among 30 food handlers based on some influencing factors, such as education level, work experience, worker's behavior, and hygiene training at a public hospital in South Sumatra, Indonesia. To study the correlation between some factors with the level of $E$. coli contamination, the bivariate analysis was performed. The results of the bivariate analysis revealed that there was a significant relationship between the education level and work experience of the food handlers with the level of $E$. coli contamination (p-value $\leq 0.05$ ). In the other hand, there was no significant relationship between behavior and hygiene training with the level of E. coli contamination (pvalue $\geq 0.05$ ). This study indicates the importance of socialization about food hygiene and regular rectal swab test for food handlers to ensure their health level.
\end{abstract}

Keywords: Escherichia coli, rectal swab, hygiene, infection, bivariate analysis

\section{Introduction}

Food handlers working in hospitals are people who directly involved in the food chain processing until the food distribution to the patients. The role of food handlers in spreading diseases is the contact between food handlers suffering infectious diseases with the food source itself. Subsequently, the food is consumed by the patient and causes nosocomial infections.

Food handlers who work in the food service sector with poor personal hygiene are the potential source of pathogenic organism infection (Acikel et al., 2008; Mukhopadhyay et al., 2016; Anjum et al., 2017; Gemeda et al., 2018). The food contamination occurs during food chain process including preparation, production, processing, and the food distribution (Permenkes RI, 2011; Anuradha and Dandekar, 2014; Mukhopadhyay et al., 2016). The risk of bacteria contamination to the food 
handlers depends on their health status, personal hygiene, knowledge, and the hygiene practice (Esparar et al., 2010; Dahiru et al., 2016).

Foodborne disease is defined as illness resulting from the consumption of contaminated food; food can be contaminated with microbial pathogens or a toxic substance (Unicomb, 2009). Most of the foodborne diseases happen because the food handlers have transmitted the bacteria or viruses through improper food handling and poor sanitation. The hands of food-handlers can serve as vectors in the spread of foodborne diseases due to poor personal hygiene or cross-contamination. Recent days, the food-borne diseases become a major health problem in developing countries, such as Ethiopia (Girma et al., 2017; Gemeda et al., 2018), Nigeria (Dahiru et al., 2016), Iran (Heydari-Hengami et al., 2018), and Indonesia (Chantika, et al., 2016; Kurniasih et al., 2015). The global incidence of food-borne diseases is difficult to estimate, but it was reported that in 2005 there were 1.8 million people killed from diarrheal diseases. This case can be linked to food and drinking water pollution (WHO, 2007, 2008).

As located in a developing country, the health problem is one of the concerning issues in Palembang, South Sumatra-Indonesia. The public hospital in South Sumatra serves many patients every day. Based on the preliminary research, the supervision of food hygiene and sanitation by the Environmental Health Department and the Nutritional Departments should be improved to ensure the public hospital sanitation. In the other hand, the Department of Infectious Disease only evaluates adherence of the hygiene activities in the food sanitation. Therefore, further study is required to perform the synergistic responsible of the three departments for food sanitation and hygiene. The food processing at a public hospital in South Sumatra should be improved to ensure the quality of food services, especially for patients.

Commonly, the parameter of hygiene is the presence of Staphylococcus aureus bacteria, while the parameter of sanitation is Escherichia coli contamination. This research is focused on E. coli contamination which is found in food handlers due to the poor sanitation of the hospital's workers (Hanekom et al., 2010; Kurniasih et al., 2015; Switaj et al., 2015; Dahiru et al., 2016; Nasrolahei et al., 2016). Escherichia coli or commonly abbreviated as $E$. coli is one of the common gram-negative bacteria. In general, these bacteria can be found in the human colon and feces (Switaj et al., 2015; Nasrolahei et al., 2017). Most of E. coli is harmless, however, E. coli type O157: H7 can cause bloody diarrhea because produces verotoxins (Lourenco et al., 2011; Switaj et al., 2015).

This study was to overview the $E$. coli contamination among food handlers at a public hospital in South Sumatra and also analyzes the factors affecting $E$. coli contamination among food handlers at the Nutrition Department at a public hospital in South Sumatra. In addition, this research also offers an effort to reduce the risk of $E$. coli contamination in the food handlers.

\section{Materials and methods}

This study was a cross-sectional design including data collection simultaneously with a descriptive quantitative approach, bacteria investigation, and factors that influence the health rate of food handlers at a public hospital in South Sumatra. The study was conducted to determine bacteria contamination among 30 food handlers at a public hospital in South Sumatra, as the population in this study. The dependent variable was E. coli contamination on food handler's sample. The independent variables were 
education level, work experience, behavior, and hygiene training. The education level was divided into two sub-variables, which consisted of a middle (senior high school) and low (elementary and junior high school). The work experience was divided into two sub-variables which consisted of more and less than 3 years. The worker's behavior was divided into two sub-variables which consist of following and not following Standard Operation Procedure. The hygiene training was also divided into two sub-variables, which consist of attending and not attending the training related to the hygiene process.

Interviews were conducted with all food handlers working at the hospital. Total of 30 respondents was interviewed and 30 samples of rectal swabs were obtained from the corresponding workers for further testing. Preparation of the bacteria samples follows the WHO standard (WHO, 2003) using a rectal swab for E. coli bacteria (Esparar et al., 2004). Swab sampling and laboratory identification were analyzed in the Laboratory of Environmental Health Center Palembang.

Bivariate analysis was carried out to investigate the quantitative distribution of independent and dependent variables. Bivariate analysis was also performed to examine the correlation between each of the independent variables and the dependent variable. This was achieved by comparing the p-value to study the level of significance (Emzir, 2009). The factors investigated were education level, work experience, behavior, and hygiene training for staff at a public hospital in South Sumatra.

\section{Results}

The E. coli contamination shows the sanitation rate of the hospital's employees. Table 1 shows that $36.7 \%$ of the food handlers staff at a public hospital in South Sumatra are positively contaminated with E. coli, while $63.3 \%$ of them are not indicated to be contaminated with $E$. coli.

Table 1. Analysis of E. coli contamination among the food handlers a public hospital in South Sumatra

\begin{tabular}{c|c|c|c}
\hline \multirow{2}{*}{ No } & \multirow{2}{*}{ Results } & \multicolumn{2}{|c}{ Food handlers } \\
\cline { 3 - 4 } & & Quantity & Percent (\%) \\
\hline 1. & Not contaminated & 19 & 63.3 \\
2. & Contaminated & 11 & 36.7 \\
\hline & Total & 30 & 100 \\
\hline
\end{tabular}

Bivariate analysis was carried out on the characteristics of respondents and risk factors for $E$. coli exposure, especially those with a probability value less than 0.05 ( $\mathrm{p}<0.05)$. The analysis results will describe the risk factors for $E$. coli contamination without considering the existence of other independent variables. The bivariate analysis was carried out by making a double crosstab $(2 \times 2)$, the respondent's characteristics, and the risk factors which estimated to affect the E. coli contamination.

Table 2 shows the correlation between education levels and E. coli contamination. The $\mathrm{p}$-value is 0.015 or $\mathrm{p} \leq 0.05$ indicating that there is a significant correlation between the education level and $E$. coli contamination incident.

Table 3 reveals a correlation between work experience and E. coli contamination incident. The obtained $\mathrm{p}$-value is 0.02 or $\mathrm{p} \leq 0.05$ indicating the significant correlation between work experience and the E. coli contamination. 
Table 4 shows correlation between food handler's behavior and E. coli contamination. The $\mathrm{p}$-value is 0.37 or $\mathrm{p} \geq 0.05$ indicating no significant correlation between worker's behavior and the $E$. coli contamination.

Table 5 shows the correlation between training related to the food handler's job and $E$. coli contamination. The $\mathrm{p}$-value is 0.15 or $\mathrm{p} \geq 0.05$ indicating that there is no significant correlation between the training profile and $E$. coli contamination incident.

Table 2. Correlation between education level and E. coli contamination

\begin{tabular}{c|c|c|c|c|c}
\hline \multirow{2}{*}{ E coli } & \multicolumn{4}{|c|}{ Education level } & \multirow{2}{*}{ p-value } \\
\cline { 2 - 5 } & Low & \% & Middle & \% & \\
\hline Negative & 1 & 5 & 19 & 95 & \\
Positive & 4 & 40 & 6 & 60 & 0.015 \\
Total & 5 & 16.7 & 25 & 83.3 & 30 \\
\hline
\end{tabular}

Table 3. Correlation between work experience and E. coli contamination

\begin{tabular}{c|c|c|c|c|c}
\hline \multirow{2}{*}{$\boldsymbol{E}$ coli } & \multicolumn{4}{|c|}{ Work experience } & \multirow{2}{*}{ p-value } \\
\cline { 2 - 5 } & $<\mathbf{3}$ years & $\mathbf{\%}$ & $>\mathbf{3}$ years & $\boldsymbol{\%}$ & \\
\hline Negative & 6 & 30 & 14 & 70 & \\
Positive & 9 & 90 & 1 & 10 & 0.02 \\
Total & 15 & 50 & 15 & 50 & 30 \\
\hline
\end{tabular}

Table 4. Correlation between behavior of food handlers and E. coli contamination

\begin{tabular}{c|c|c|c|c|c}
\hline \multirow{2}{*}{$\boldsymbol{E}$ coli } & \multicolumn{4}{|c|}{ Behavior } & \multirow{2}{*}{ p-value } \\
\cline { 2 - 5 } & Following SOP & $\mathbf{\%}$ & Not following SOP & $\boldsymbol{\%}$ & \\
\hline Negative & 6 & 30 & 14 & 70 & \\
Positive & 7 & 70 & 3 & 30 & 0.37 \\
Total & 13 & 43.3 & 17 & 56.7 & 30 \\
\hline
\end{tabular}

Table 5. Correlation between food handler's training and E. coli contamination

\begin{tabular}{c|c|c|c|c|c}
\hline \multirow{2}{*}{ E coli } & \multicolumn{4}{|c|}{ Training } & \multirow{2}{*}{ p-value } \\
\cline { 2 - 5 } & No & \% & Yes & \% & \\
\hline Negative & 2 & 10 & 18 & 90 & \\
Positive & 5 & 50 & 5 & 50 & 0.15 \\
Total & 7 & 23.3 & 23 & 76.7 & 30 \\
\hline
\end{tabular}

\section{Discussion}

E. coli contamination is exclusively coming from fecal. It is transmitted through the fecal contamination of food and water, as well as cross-contamination, and by human contact during the food preparation. Meanwhile, the primary contamination source is the consumption of contaminated food, such as undercooked food or raw milk. For this reason, Lambrechts et al. (2014) proposed that E. coli contamination of the hands of 
food handlers as an indicator of a hand-washing efficiency. The hands of ready-to-eat food service food handlers have been the main vector for spreading food-borne diseases. Furthermore, Howes et al. (1996) stated that improper food handlers practice contributed up to $97 \%$ of foodborne illnesses in food service establishments and homes. Even, the study of Wilson et al. (2017) revealed that food poisoning originated from the catering industry contributed $70 \%$ higher than that caused by other sectors.

Factors affecting E. coli contamination of food handlers include the knowledge and the food handling process. The food handler's responsibilities include providing the foodstuffs, storing the foodstuffs, processing the food, and distributing the food to patients or other hospital staffs. Our investigation reveals that there are still less than $50 \%$ of food handlers at a public hospital in South Sumatra who work not in accordance with the SOP. The reason given by workers regarding this problem is they are not familiar and they feel uncomfortable when using the work equipment (apron, gloves, head cover, etc.).

A total of $63.3 \%$ of food handlers are not indicated in E. coli contamination, while $36.7 \%$ of food handlers are indicated $E$. coli contamination. In general, $75 \%$ of the food handlers worker a public hospital in South Sumatra have a high school education background, $33.3 \%$ of them still have work experience less than 3 years, $26.7 \%$ of them do not follow the SOP in their work, and $33.3 \%$ of them have never attended the formal training related to their work.

These results are in accordance with the previous study conducted by Lazarevic et al. (2013). They revealed that the most general isolated bacteria in food handler's cases are E. coli. Another study by Nasrolahei et al. (2016) showed that there were $29.2 \%$ of 220 respondents contaminated with E. coli bacteria. Oundo et al. (2008) studied E. coli contamination of food handlers in three different locations in Kenya. They got 1.2\% samples in Diani, 4\% samples in Malindi, and $1.8 \%$ samples in Nairobi are contaminated by $E$. coli.

By finding a significant relationship between work experience, the food handler's behavior, and the $E$. coli contamination; special attention is required to improve the employee's behavior. The effort to reduce contamination of E. coli bacteria at a public hospital in South Sumatra is by providing socialization or related training about hygiene implementation as well as regular health checks for the food handlers. Because $36.7 \%$ of food handlers at a public hospital in South Sumatra are infected with E. coli, it is necessary to have rectal swab test intensively to check the health level of the food handlers. This suggestion is in accordance with several studies conducted by El Derea et al. (2008), Lazarevic et al. (2013), Ngivu (2016), Sande et al. (2014), Sharif et al. (2013, 2015), and Zaglool, et al. (2011).

\section{Conclusion}

A total of $36.7 \%$ of food handlers at a public hospital in South Sumatra are indicated to have $E$. coli contamination. The results of the bivariate analysis show that some factors including the education level and work experience significantly affected the risk of $E$. coli contamination. In the other hand, there is no significant correlation between the behavior of the food handlers and hygiene training with the E. coli contamination level. This study revealed the importance of socialization about food hygiene and regular rectal swab test for food handlers to reduce the risk of E. coli contamination among the food handlers. Future studies may include investigation of other bacteria and 
viruses that might contaminate the food handlers as well as the effectiveness of lathering on bacteria removal from hands.

\section{REFERENCES}

[1] Acikel, C. H., Ogur, R., Yaren, H., Gocgeldi, E., Ucar, M., Kir, T. (2008): The hygiene training of food handlers at a teaching hospital. - Food Control 19: 186-190.

[2] Anjum, W., Kalasker, P. S., Bhaskar, K. (2017): Prevalence of intestinal parasites and its associated socio-demographic factors among the food handlers of Bagalkot city, Karnataka, India. - Int J Community Med Public Health 4(1): 1-4.

[3] Anuradha, M., Dandekar, R. H. (2014): Knowledge, attitude and practice among food handlers on food borne diseases: a hospital based study in tertiary care hospital. - IJBAR 5(4): 196-198.

[4] Chantika, I., Sumardianto, D., Sumaningrum, N. D. (2016): Higiene penjamah dan sanitasi pengeloaan makanan di Instalasi Gizi Rumah Sakit Umum Daerah Gambiran Kota Kediri. - Jurnal Preventia 1(1): 7-13.

[5] Dahiru, J. Y., Abubakar, F. A., Idris, H., Abdullahi, S. A. (2016). Bacterial contamination of food handlers at various restaurants in Kano State Metropolis, Kano Nigeria. - Int. J. Curr. Microbiol. App. Sci. 5(5): 165-170.

[6] El Derea, H., Salem, E., Fawzi, M., Azeem, M. A. (2008): Safety of patient meals in 2 hospitals in Alexandria, Egypt before and after training of food handlers. - Eastern Mediterranean Health Journal 14(4): 941 - 952.

[7] Emzir (2009): Metodologi Penelitian Pendidikan. - PT Raja Grafindo Persada, Jakarta.

[8] Esparar, D. G., Belizario, V. Y., Relos, J. R. D. (2004): Prevalence of intestinal parasitic infections among food handlers of a tertiary hospital in manila using direct faecal smear and formalin ether concentration technique. - Phil J Microbiol Infect Dis 33(3): 99-103.

[9] Gemeda, T. I., Asayehu, T. T., Abdisa, M., Fekadu, H. (2018): Assessment of knowledge, attitude and practices of food handlers in Nekemte Referral Hospital, Wollega, Ethiopia. - J Nutr Health Food Eng. 8(1): 87-92.

[10] Girma, H., Beyene, G., Mekonnen, Z. (2017): Prevalence of intestinal parasites among food handlers at cafeteria of Jimma University Specialized Hospital, Southwest Ethiopia. - Asian Pac J Trop Dis 7(8): 467-471.

[11] Hanekom, S. M., Vermeulen, E. E., Oldewage-Theron, W. (2010): Food safety risk factors in a hospital food service unit serving low microbial diets to immunecompromised patients. - African Journal of Food Agriculture, Nutrition and Development 10(9): 4000-4015.

[12] Heydari-Hengami, M., Hamedi, Y., Najafi-Asl, M., Sharifi-Sarasiabi, K. (2018): Prevalence of intestinal parasites in food handlers of Bandar Abbas, Southern Iran. - Iran J Public Health 47(1): 111-118.

[13] Howes, M., McEwen, S., Griffiths, M., Harris, L. (1996): Food handler certification by home study: Measuring changes in knowledge and behaviour. - Dairy Food Environ San. 16: 737-744.

[14] Kurniasih, R. P., Nurjajuli, Hanani, Y. D. (2015): Hubungan Higiene dan Sanitasi Makanan Dengan Kontaminasi Bakteri Escherichia coli dalam makanan di warung makan sekitar terminal Borobudur, Magelang. - Jurnal Kesehatan Masyarakat 3(1): 549558.

[15] Lambrechts, A. A., Human, I. S., Doughari, J. A., Lues, J. F. R. (2014): Bacterial contamination of the hands of food handlers as indicator of hand washing efficacy in some convenient food industries in South Africa. - Pak. J. Med. Sci. 30(4): 755-758.

[16] Lazarevic, K., Stojanovic, D., Bogdanovic, D. C., Dolicanin, Z. C. (2013): Hygiene training of food handlers in hospital settings: Important factor in the prevention of nosocomial infections. - Cent Eur J Public Health 21(3): 146-149. 
[17] Lourenco, A., Carneiro, S., Pinto, J., Rocha, M., Ferreira, E. C., Rocha, I. (2011): A study of the short and long-term regulation of E. coli metabolic pathways. - Journal of Integrative Bioinformatics 8(3): 183-198.

[18] Mukhopadhyay, S., Malpekar, K., Shastri, J. (2016): Intestinal parasitic and bacterial infection among food handlers in a metropolitan tertiary care hospital. - J. Evolution Med. Dent. Sci. 5(62): 4327-4331.

[19] Nasrolahei, M., Mirshafiee, S., Kholdi, K., Salehian, S., Nasrolahe, M. (2017): Bacterial assessment of food handlers in Sari City, Mazandaran Province, North of Iran. - Journal of Infection and Public Health 10: 171-176.

[20] Ngivu, J. (2016): Impact of food handlers' food safety training in a paediatric hospital in East Africa. - American Journal of Infection Control 44: S28-S82.

[21] Oundo, J. O., Kariuki, S. M., Boga , H. I., Muli , F. W., Iijima, Y. (2008): High incidence of enteroaggregative Escherichia coli among food handlers in three areas of Kenya: A possible transmission route of travelers diarrhea. - Journal of Travel Medicine 15(1): 3138.

[22] Permenkes RI No 1096 (2011): Higiene Sanitasi Jasaboga - Kementerian Kesehatan Republik Indonesia, Jakarta.

[23] Sande, S., Basak, S., Sande, V., Tawade, V. (2014): Screening of food handlers for intestinal parasites and enteropathogenic bacteria in a tertiary care hospital. International Journal of Health Sciences \& Research 4(5): 88-94.

[24] Sharif, L., Obaidat, M. M., Al-Dalalah, M. R. (2013): Food hygiene knowledge, attitudes and practices of the food handlers in the military hospitals. - Food and Nutrition Sciences 4: 245-251.

[25] Sharif, M., Daryani, A., Kia, E., Rezaei, F., Nasiri, M., Nasrolahei, M. (2015): Prevalence of intestinal parasites among food handlers of Sari, Northern Iran. - Rev. Inst. Med. Trop. Sao Paulo 57(2): 139-144.

[26] Switaj, T. L., Winter, K. J., Christensen, S. R. (2015): Diagnosis and management of foodborne illness. - Am. Fam. Physician 92(5): 358-365.

[27] Unicomb, L. E. (2009): Food Safety: Pathogen transmission routes, hygiene practices and prevention. - J. Health Popul. Nutr. 27(5): 599-601.

[28] WHO (2003): Basic Laboratory Procedures in Clinical Bacteriology. - World Health Organization, Geneva.

[29] WHO (2007): Food Safety and Foodborne Illness. Fact Sheet No. 237. - World Health Organization, Geneva.

[30] WHO (2008): WHO Initiative to Estimate the Global Burden of Foodborne Diseases. World Health Organization, Geneva.

[31] Wilson, M., Murray, A. E., Black, M. A., McDowell, D. A. (1997): The implementation of hazard Analysis and critical control points in hospital catering. - Manag Serv Qual 7(3): 150-156.

[32] Zaglool, D. A., Khodari, Y. A., Othman, R. A. M., Farooq, M. U. (2011): Prevalence of intestinal parasites and bacteria among food handlers in a tertiary care hospital. Nigerian Medical Journal 52(4): 266-270. 